DOI https://doi.org/10.30525/978-9934-26-073-5-2-63

\title{
ВИВЧЕННЯ ЛЕКСИЧНИХ НОРМ УКРАЇНСЬКОЇ МОВИ ІНОЗЕМНИМИ СТУДЕНТАМИ В ПРОЦЕСІ ВИКЛАДАННЯ КУРСУ «УКРАЇНСЬКА МОВА ЗА ПРОФЕСІЙНИМ СПРЯМУВАННЯМ»
}

\author{
Боть Л. П. \\ кандидат філологічних наук, \\ доцент кафедри методики навчання, \\ стилістики й культури украӥнської мови \\ Черкаського національного університету імені Богдана Хмельницького \\ Красовська О. М. \\ кандидат філологічних наук, \\ дочент кафедри методики навчання, \\ стилістики й культури украӥнської мови \\ Черкаського національного університету імені Богдана Хмельницького
}

\section{Руденко В. М.}

кандидат педагогічних наук,

доцент кафедри методики навчання, стилістики й культури украӥнської мови

Черкаського національного університету імені Богдана Хмельниџького м. Черкаси, Україна

Набуття комунікативної й культурологічної компетентності, удосконалення мовлення відповідно до усталених норм у соціокультурній, навчально-професійній сфері - основне завдання українськомовної підготовки студентів-іноземців. Для навчання української мови як іноземної особливо важливою $є$ практична цінність навчання, функційний підхід до відбору й подання матеріалу, ситуативно-тематична спрямованість навчального матеріалу, вивчення лексики на синтаксичній основі (орієнтація на контекст) [1, с. 43].

Під час опанування курсу української мови за професійним спрямуванням у Черкаському національному університет ім. Богдана Хмельницького (22 год.) особливої специфіки набуває робота з вивчення лексичних норм. У зв'язку з неправильним слововживанням виникають труднощі 3 адекватним вираженням думки, внаслідок чого часто 
трапляються комунікативні невдачі. У процесі навчання лексичних норм іноземних студентів перед викладачем ЗВО постають такі завдання: 1) подолати труднощі лексичного рівня, що притаманні саме іноземним студентам; 2) усунення явища інтерференції, викликаного впливом певної мови; 3) формування лінгвокультурологічної компетенції 3 урахуванням особливостей мовної картини світту носіїв української мови та інших мов; 4) попередження культурного шоку, який може виникнути в результаті недостатньої уваги до проблем міжкультурної комунікації.

Успішно вирішити поставлені завдання дозволяє курс української мови в ЗВО, у якому виокремлено модуль «Лексичні мовні норми». Роботу з лексикою української мови побудовано на основі поетапного вивчення особливостей лексичної норми, занурення в лексичне значення й лексичні зв'язки слова. Далі прокоментуємо основні особливості навчання лексики для іноземців, подамо типи завдань, які спрямовані на формування лексичних умінь.

Першою особливістю в навчанні лексики $є$ точність слововживання.. Вивчаючи точність як одну з головних комунікатвиних ознак культури української мови, студенти особливо звертають увагу на близькі за звучанням, але різні за значенням лексичні одиниці; на близькі за значенням спільнокореневі слова, які лише частково збігаються за значенням із лексемами рідної мови студентів-іноземців (міністр міністерство -мінізахід). У лексичній системі української мови існує значна кількість багатозначних слів, які студенти-іноземці порівнюють зі словами своєї рідної мови й простежують суттєву відмінність або збіг у значенні лексичної одиниці (діалектика - діалект, економклас економія, аквапарк - акваріум). Крім того, використання багатозначних слів української мови потребує розуміння контексту: блискучий погляд, блискуча відповідь, блискучий одяг. Викладач української мови для студентів-іноземців має враховувати, що деякі слова української мови можна перекласти рідною мовою студента (атом), а є такі, що означають абсолютно різні поняття (госпіталь (в англійській мові немає нічого спільного з військовою лікарнею); студент (в анлійській мові учні зош теж студенти). До того ж, для іноземців українські прикметники чорний, білий є іменниками (така мовленнєва практика в українській мови не $\epsilon$ поширеною). Слід зауважити, що деякі етикетні формули представлення, наприклад: мене звати Іван / моє ім'я Іван іноземні студенти не сприймають як синонімічні.

Досить проблематично для студентів-іноземців опанувати царину слів-інтернаціоналізмів, які вживаються разом з питомими українськими лексемами, які близькі, але тотожні за значенням до іноземних. Із метою 
досягнення точності в мовленні необхідно знати відтінки обох значень слова, їх стилістичні особливості, умови контекстуації. Деякі українські лексеми, які мають в інших мовах подібну будову, суттєво відрізняються за значенням.

Багатство української лексики виявляється в наявності значної кількості паронімів. Навчаючи іноземних студентів правильно вживати слова такого шару лексики, викладач має розділити пароніми на дві групи: 1) пароніми 3 інтернаціональним коренем, які часто перекладаються рідною мовою одним словом (психологічний - психічний); 2) пароніми, які мають український корінь, який можна перекласти подібним словом, або різними лексемами (людний - людський людяний - залюднений). Для того, щоб студенти усвідомили відмінність у значеннях, із обома групами паронімів доцільно надавати достатню кількість прикладів, а тоді пропонувати ввести пароніми до тексту.

Другою особливістю у формуванні комунікативної компетентності в студентів-іноземців під час опрацювання модуля «Лексична мовна норма» $\epsilon$ лексична сполучуваність. У різних мовах через специфіку національної мовної свідомості слова часто поєднуються по-різному. Наприклад, 3 іменником «запитання» в українській мові поєднується дієслово «ставити», в англійській - запитувати запитання (to ask a question), в іспанській - робити запитання (hacer uma pregunta), у російській - задавати (задавать вопрос). Тому дослівний переклад багатьох словосполучень 3 інших мов українською часто помилковий. Щоб подолати таку інтерференцію, рекомендуємо використовувати завдання, які скеровані на порівняння сполучуваності конкретних лексичних одиниць в українській і рідній мові, на досконалість контекстного вживання українських словосполучень.

Третя оосбливість вивчення лексичних норм полягає у виразності й доречності словоживання. Щоб досягти максимальної виразності мовлення, необхідно працювати над посиленням словникового запасу, покращувати вміння користуватися всіма пластами української лексики: синонімами, антонімами, фразеологізмами, без яких неможливе уявлення про український менталітет, мовну картину світу. При цьому викладач української мови для студентів-іноземців має навчити доречно вживати лексеми в мовленнєвому потоці, враховуючи умови комунікативної ситуації.

Цілеспрямована робота щодо закріплення лексичних норм студентами-іноземцями побудована на основних методичних принципах, які визначаються послідовністю й доступністю навчального матеріалу; зв'язком лексичного й словотворчого рівнів мови; умотивованістю й 
комунікативною спрямованістю мовних завдань; скерованістю завдань на використання лінвістичних знань і набутого досвіду студентом у процесі вивчення української мови (встановлення паралелей, знаходження спільного й відмінного, вияв збігів лексичних систем). Апробація описаної методики на заняттях з англо-, франко-, арабомовними студентами підтвердила свою ефективність.

\title{
Література:
}

1. Бей Л. Б. Проблеми викладання української мови різним категоріям іноземних студентів Вісник Харківського національного університету ім В. Н. Каразіна № 12. С. 42-49.

2. Туркевич О. Методика викладання української мови як іноземної: розвиток науки і становлення терміна Теорія $і$ практика викладання української мови як іноземної. 2009. Вип. 4. С. 137-144

DOI https://doi.org/10.30525/978-9934-26-073-5-2-64

INNOVATIVE TEACHING... IS IT MY PAIR OF SHOES?

\section{Dobrovolska N. D.}

English teacher of higher category, teacher-methodist Yuriy Fedkovych Chernivtsi National University Applied College

\author{
Kuzyk O. V. \\ English teacher of the first category \\ Yuriy Fedkovych Chernivtsi National University Applied College \\ Chernivtsi Ukraine
}

Teaching can be defined as the systematic presentation of facts, skills, ideas and techniques to students. An analogous concept to teaching is pedagogy that can be defined as the art or profession of teaching. There is a personal exchange between the mind of a teacher and that of a student. The teacher demonstrates to the students how to recognize the truth, think for themselves, and encourages intellectual and analytical responses. Teachers are also active listeners.

A language is a part of a culture, and a culture is a part of a language; the two are intricately interwoven so that one cannot separate the two without losing the significance of either language or culture. "The acquisition of a second language (...) is also the acquisition of a second culture.» [7, c. 177]. 